fulcrum to the roof of the pharynx, so as by their contraction to raise the roof, to enlarge the cavity, and to turn it into a forcing pump. When the pharynx is not so distended its roof is arched upwards and its lumen on cross-section merely a transverse slit. Above itwithin the hollow of the arch-is a system of radiating muscles which increase the curvature of the pharynxroof and so close it unless when antagonised by the descending muscles.

8. Except by the muscles, and at its inferior margin, the fulcrum has no organic connection with the pharynx. As the fulcrum transverses the length of the head, free externally of the outer wall of the head, and free internally of the proboscis which pierces it though separated from it, and as it is enclosed by muscles on both sides, it must be endoskeletal in its nature, $i . e$., an ingrowth from the exoskeleton, like the endophragms of the thorax or the endocranium of the head of other insects.

I2 Dec. I 884 .

\title{
NOTES ON SOME COLEOPTERA TAKEN IN SOUTH LOUISIANA.
}

BY CHARLES HENRY TYLER TOWNSEND, CONSTANTINE, MICH.

The whole of Louisiana has been inciuded by Leconte in the southern province of his great Atlantic district. ${ }^{1}$ It would seem however, upon further consideration of the fauna, that the southern strip parallel with the coast should be connected with his "subtropical province, including the seacoast of Texas" (see map by Leconte); which, moreover, as he says, "belongs more properly to the eastern province of the tropical zoological district of Mexico.",2 It was in what might be called the subtropical province of the seacoast of Louisiana (being a continuation of the coast strip embraced in the eastern province of Mexico) that these notes were

\footnotetext{
1 Leconte, J : L. The coleoptera of Kansas and eastern New Mexico; with map showing the entomological provinces of North America. Wash., Smithsonian insti. tution, $1859, \mathrm{p}$. iv.

2 Loc. cit., p. iii-iv.
}

collected, and the observations here given made.

It will be borne in mind that at the time of my visit, 29 March to 2 I June I884, a large tract of country near Bayou la Fourche was overflowed from the great crevasse of March the same year. For the identification of most of the species to which these notes refer, I am indebted to the kindness of Dr. G: H : Horn.

The cicindelidae seemed to be nearly absent or of local occurrence in southern Louisiana, and not to frequent the low lands of that part of the state. I saw only two specimens of this family (one larva of Tetracha carolina, and one Cicindela repanda) in the latitude of New Orleans. Afterwards I saw $C$. tortuosa with $C$. repanda at the mouth of Red River. Though I risit- 
ed Lake Pontchartrain several times in the first part of April, and also on 19 and 20 June, I could find no traces of Cicindela at all then, either on the beach or elsewhere. They are probably found here, however, at other times of the year. Not one was to be seen in the low country along Bayou la Fourche during April, May and June. Leaving New Orleans, and going up the river, I found them more plentiful in the higher country in the northern part of the state. They occur all along the river on the sand flats above the levee system and on the sandy mudbanks of the lower river.

Brachynus tormentarius is abundant under old wood in moist places. This is a much larger species than our northern bombardiers, and emits its explosions vigorously and with continued frequency, causing great pain unless carefully handled. Kirby and Spence state that they were informed by M. Lacordaire that the burning sensation arising from the discharges of the large exotic species was so painful that he had often been obliged to let those which he had taken escape. $^{8}$ 'This species may be among those to which M. Lacordaire had reference; it is certainly one of the "large exotic species." These beetles have a way of curling the tip of the abdomen up so as to eject the burning liquid not only behind and on each side but also frontwards over the back, and it is often expelled in drops, and to a considerable distance. The bombardiers all seemed, when a log was rolled over,

\footnotetext{
3 Kirby and Spence's Entomology, $7^{\text {th }}$ ed., p. 419.
}

to take the alarm from the one which first detected the danger and gave the signal by emitting its explosion; for all the others, wherever they might be, would follow with their explosions as soon as they heard that of one of their number. By this habit I often discovered individuals that had hidden in holes, or under leaves in the dirt.

In the flooded forest growths near Bayou la Fourche I found several of the ground-frequenting carabidae (Chlaenius fuscicornis, C. laticollis and others) under chips upon stumps that rose above the water. So this is how the carabs fared in their flooded home, taking to stumps and logs in default of the ground! Arboreal forms of these genera might be produced in this way, if inundation were to prevail for a sufficient length of time and the trees themselves continued to flourish in the water as well as before. Before the levee system was constructed the coleoptera as well as the other animals of southern Louisiana were undoubtedly accustomed to the periodical inundations caused by the risings of the Mississippi forcing them to seek habitation elsewhere than on the ground. The ground-frequenting species that survived probably then took to stumps and $\operatorname{logs}$, as in the present instance; while others confined themselves to the foliage or bark of the trees, which previously had been frequented by them only a portion of the time. And thus they lived until the waters subsided and allowed them to betake themselves to their old retreats. Perhaps this ac- 
counts for the scarcity of the cicindelidae, and the absence of Calosoma (not a specimen of which could be found) in that part of the state. I might add in this connection that I also took a pair of Eudocimus mannerheimii, besides some cerambycidae (Leptura abdominalis) and some other coleoptera all on one stump a good distance out in the flooded forest.

Not a specimen of the silphidae was taken; this is undoubtedly owing to the great numbers of buzzards, which effectually clean up every thing in the shape of carrion.

I noticed that specimens of Dicerca obscura, instead of taking immediate flight when alarmed, loosed their hold from the plants (wormwood [Artemisia] and ragweed [Ambrosia]) to which they were clinging, and dropped to the ground like weevils; which is a far more inactive mode of escape than that employed by some others of this family, for example Chrysobothris femorata.

Chauliognathus marginatus, which is very abundant upon patches of blossom in the South, seems to prefer yellow flowers, as its color assimilates better with the yellow; and upon these it is generally found. Though it is sometimes found upon white daisies, the stigmata of these are yellow, and help to blend the color of the insect with that of the flower. I noticed on I 7 April that many of these insects were infested with a little red mite.

I took a specimen of Neoclytus erythrocephalus on a tuft of the common ragweed [Ambrosia artemisiaefolia], I8 May. Clinging in the green foliage of the weed, this cerambycid, with the four bright yellow transverse markings of its elytra continuing clear around the body, resembled exactly at first sight a species of hornet or wasp which has the abdomen encircled with yellow bands, so that I hesitated a moment before capturing it. Its slender and cylindrical form and long legs so like a wasp's combine with the bright yellow bands to make up a deception calculated to imbue more animals than one with the dread of a concealed sting ready to prove effective should they have the audacity to meddle with it.

I noted an interesting fact relating to sexual selection in Desmocerus palliatus. These beetles are quite abundant on the elder leaves [Sambucus] in April, at this time pairing. On 22 April I noticed a very brightly colored pair in coitu upon a leaf, and on another leaf right by them an individual which had the orange bases of the elytra not nearly so bright or deeply colored as usual, but looking faded. On 27 April I observed a similar instance of a brightly colored pair with a dull colored, lone individual near by. This shows that the dull-colored individuals do not stand much chance of pairing, but that the bright ones select each other. Dull ones are not very common, and are probably of chance occurrence. I noticed that this species was much more plentiful on the leaves on cold and cloudy days than on warm and bright ones.

One morning, going by a wood-pile, I heard something suddenly drop from above and strike on one of the lower 
sticks of wood. Supposing it to be a beetle, I looked carefully and found a specimen of Acanthoderes quadrigibbus, apparently lifeless, but lively enough as soon as I picked it up.

This species almost invariably drops when approached. In color it assimilates so well with the whitened boards, or other old, weathered pieces of wood to which it may be clinging, that it is often difficult to detect it. The habit of dropping and remaining perfectly motionless for a short time has been acquired by many coleoptera as a means of escape from some of their many enemies. But in this instance the beetle, instead of escaping, drew my attention right upon it by this habit.

When Mecas inornata sees any one approaching towards it, at some distance, it generally takes wing and flies a long ways; but if one is very near and about to capture a specimen it usually drops and feigns death.

Plagiodera scripta was abundant in all stages on some cottonwood or poplar sprouts [Populus monilifera] along a ditch on a plantation. The editors of the American entomologist have illustrated several variations in the elytral markings of this species. ${ }^{4}$ But of the forty-three specimens taken by me in Louisiana every one is of the normal form. I did not notice that the species injured any planted cottonwoods here at this time.

On stems of elder [Sambucus] (also taken on young poplar or cottonwood sprouts) the little black Chalco. dermus aeneus was quite abundant. These hard, finely punctured, chunky

4 American entomologist, 188o, v. 3, p. 160. little weevils take up their positions at the joints of the elder stalks, and thus easily pass for leaf-buds just appearing, and still enveloped in their dark red (nearly black) outer coverings. This is a very interesting and effective deception.

I took thirty-six specimens of Rhodobaenus 13-punctatus. These show considerable variation in the elytral markings. Twenty-three have the thirteen spots more or less clearly defined; eleven have the two posterior and innermedial spots united in one marking extending over both elytra; one has the two posterior, inner-medial and anterior spots united in one large marking, leaving only the outer-medial on each elytron in its normal form, and having the middle and two posterior prothoracic spots united, leaving the shield three-marked; and one is well defined, I I-punctate, having none of the spots united, but with the two outer-medial entirely wanting.

One day I noticed an individual of this species upon a plant that had been overrun by a party of ants. The weevil was rumning up and down trying to escape from its hymenopterous enemies, which kept running over it and attacking it. All the while it gave forth an agreeable scent very similar to peppermirit; agreeable to me, but perhaps not to the ants, to repel whom it might have been intended. The scent did not seem to arrest the progress of the ants in the least, and the "sheath-wing" would probably have succumbed to the "vein-wings" in the end, had I not rescued the former for my collecting bottle. 

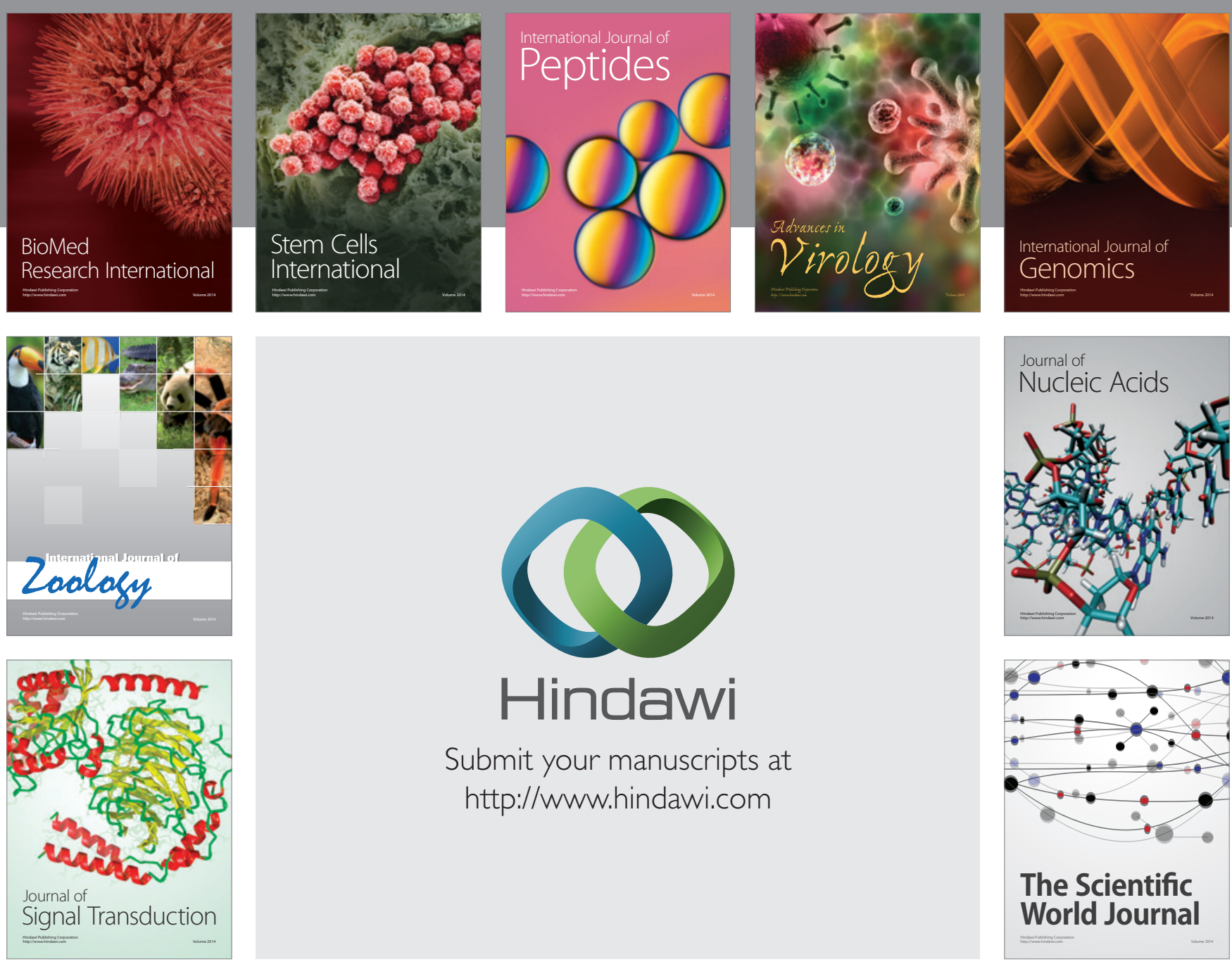

Submit your manuscripts at

http://www.hindawi.com
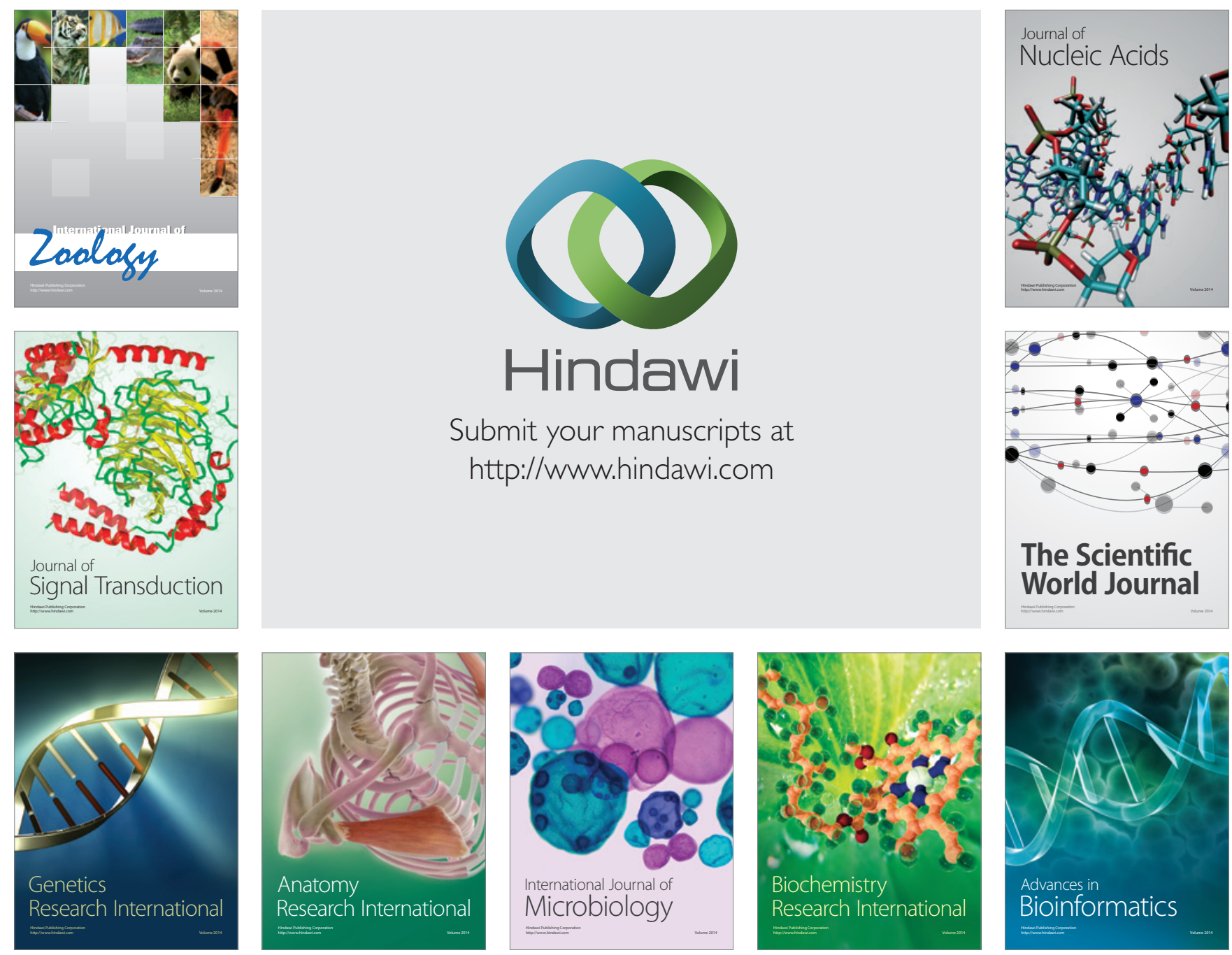

The Scientific World Journal
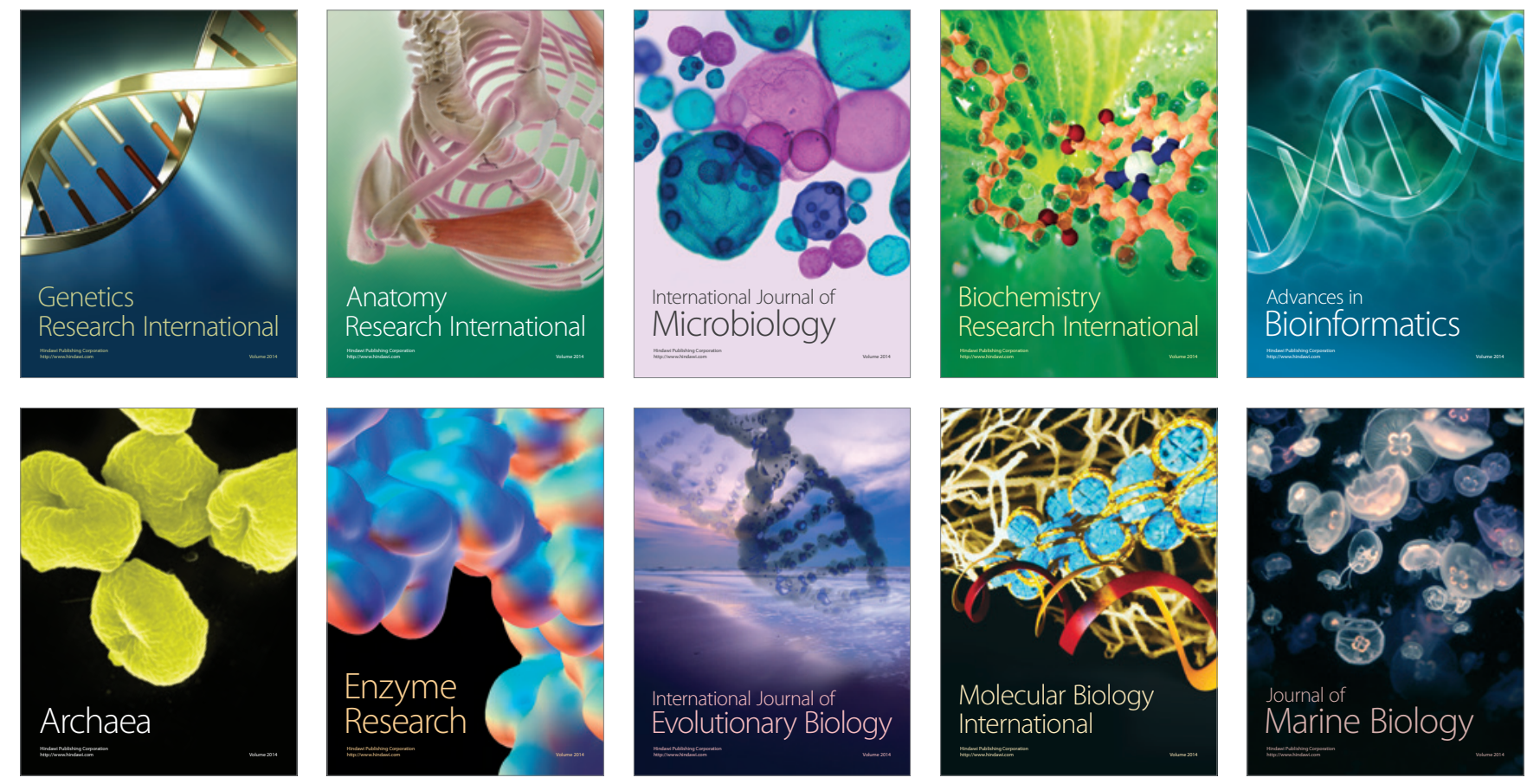